\title{
Organizational Culture in Management Small Medium Enterprises on Pandemic Period
}

\author{
Bintang Andini ${ }^{*}$, Bagas Wicaksono ${ }^{2}$ \\ ${ }^{1}$ Student of Accounting Profession Program, Faculty of Economic and Business, Universitas \\ Diponegoro - Indonesia \\ ${ }^{2}$ Student of Master of Management, Faculty of Economic and Business, Universitas Diponegoro - \\ Indonesia
}

\begin{abstract}
Many small-medium enterprises are to be close in the pandemic period. On the other hand, some SMEs still survive by making innovations in their business. Organizational culture is an essential thing in managing SMEs in Semarang City. Organizational culture in SMEs composes ethic organization and does with an example; makes code ethics and policy about ethics; has positive work environment; response fraud report constantly; does training about fraud care, and checks employee background. This study aims to answer the question of the role of organizational culture in management SMEs in Semarang City during the pandemic period. This study applies qualitative research with an in-depth interview with the owner of SMEs in Semarang City. SMEs do new culture organizational in their business management by switching from offline sales to the online sale, applying healthy protocol on offline sales, and using delivery services for goods or transfer money to avoid meeting directly with customers in the pandemic period.
\end{abstract}

\section{Introduction}

Data from the Semarang City Cooperatives and Micro, Small and Medium Enterprises Office shows that 1,538 SMEs in Semarang City businesses have been affected by the COVID-19 pandemic. The impact of this pandemic varies from $25 \%, 50 \%$, to $75 \%$, which resulted in his business being stopped during the pandemic period. The number of SMEs in Semarang City is 17,667 , and data shows that $8.7 \%$ of SMEs in Semarang City are affected by COVID-19. SMEs in Semarang City that still survived the pandemic were 91.29\% [1]

\footnotetext{
* Corresponding author: bintangandini1@gmail.com
} 


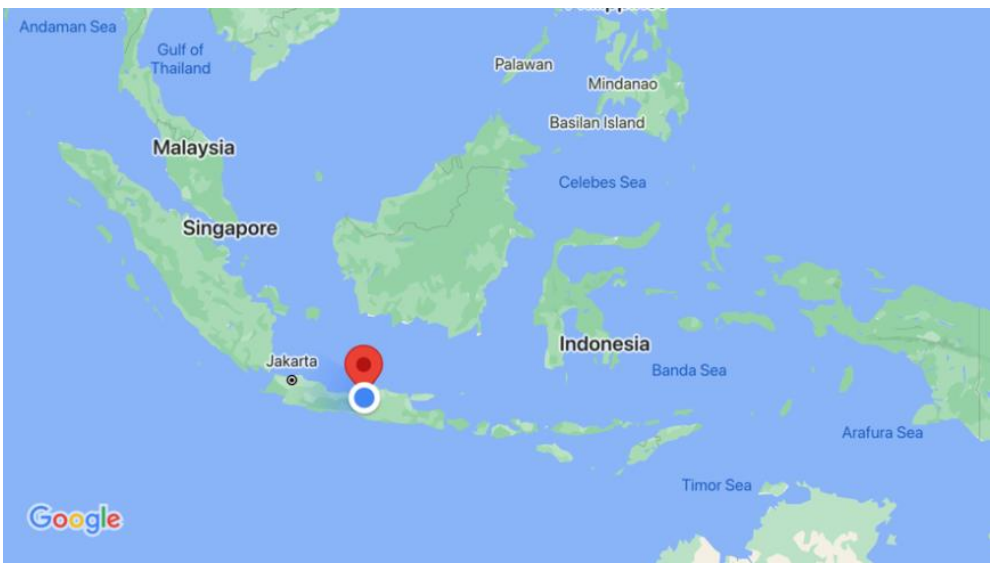

Fig. 1. The research location Semarang, Indonesia.

The functionalist paradigm assumes that organizational culture has the same function as all organizations. Organizational culture determines habits such as decision-making, such as adopting digital technology and giving identity to organizational members [2]. Organizational culture is formed when SMEs compile organizational ethics and manage them, for example: establish a code of ethics and policies regarding ethics; have a positive work environment; respond to fraud reports consistently; conduct training on fraud awareness; and background checks on employees [3].

Three essential elements of business resilience are product quality, service and process reliability. Business resilience is also supported by digital transformation. Digital transformation occurs when new digital capabilities emerge, and digital devices are adapted. The digitalization strategy is needed to achieve business goals and the development of SME products or services to be more competitive [4].

Organizational culture, environmental sustainability, and digitization have an impact on the development of the SMEs business. Dimensions related to organizational culture (attitudes, norms, and prejudices) give meaning to identity and establish habits [2]. In general, ownership and management structures such as cultural characteristics and SMEs' behaviour positively influence the knowledge management process. The behaviour of workers is more easily influenced by the philosophy and beliefs of the manager or owner [5].

The development of the model developed by Barreto (1989) and Schneider (1987) responds to system reform, system exploitation, and system protection as points that are relevant to SME management. The innovation functions as a system update. Coordination and marketing functions as system exploitation. The function of risk management is system protection [6].

SMEs can use formal management training in order to increase resilience, growth and productivity. Determining policies can improve the management skills and capabilities of SMEs owners [7]. SMEs should focus on internal and short-term planning rather than longterm planning. Organizational activities such as developing a vision and mission, internal and external communication, and change management are recommended areas to be developed [8].

This study aims to answer the question of how the role of organizational culture in the management of SMEs in Semarang City during the pandemic. Organizational culture during a pandemic is several things that SME owners do to survive. Several things have changed so that SMEs can adjust during a pandemic [8]. 


\section{Data Collection Methods}

The data collection method in this study uses primary data. Primary data were collected using the in-depth interview method with several sources. Interviews were conducted in 2020 . The resource persons came from MSME owners in Semarang City.

In depth interview is a purposeful interaction in which the interviewer tries to learn about what other people know about the topic, to reveal and record what other people have experienced, what they think and feel about it, and what it means. This process is by nature simple and intuitive.

The interviewer first contacted the source to make an appointment. The interview was conducted at the source's house. Interview activities have followed health protocols such as wearing masks and washing hands first when visiting the informant's house. Take off the mask only when taking pictures. This is not an ordinary conversation, but rather collecting data that can provide insightful analysis and produce defensible findings [9].

Selection of sources using the snowball sampling method. Snowball sampling is a random sample of individuals in a limited population [10]. After interviewing the initial sources, the researcher immediately asked for recommendations to determine the next source. After interviewing several resource persons, the results of the interviews with Mrs. Isma, Mrs. Rini and Mrs. Asih can represent the results of the interviews as a whole.

\section{Result and Discussion}

Organizational culture directs towards things that are usually done in organizations to be able to maintain ethics and the sustainability of SMEs. Each SMEs has an organizational culture or its own way of managing their SMEs. SMEs apply a new organizational culture to their business management by making several shifts. According to information from informants, here are some things that can be done so that SMEs can continue to run during a pandemic:

\subsection{The Transition from Selling Offline to Selling Online}

The interview was conducted at Mrs Isma Rahayu's house. Mrs. Isma Rahayu is the owner of SMEs Wingko Babat Cap Pohon Kelapa. She opened a wingko babat shop at his home. Her family helped her make wingko babat at home. Initially, she only served buyers who came to his house. Now she is starting to learn to register his shop in the online food delivery application.

Through this online food delivery application, she got sizeable additional sales. During a pandemic, there are no customers who come to his shop. However, Mrs Isma is very grateful because customers still buy her wares through the online food delivery application. She still benefited from selling wingko babat during the pandemic. Mrs Isma, who usually relies on buyers who come to her shop (selling offline), can now get orders through an online food delivery application (selling online) (Interview with Mrs Isma).

Some of the advantages and disadvantages of selling online. In the online market, sellers can save transaction costs and input costs that a cashier usually carries out, but the seller does not know much about the buyer's information. The seller does not need to own as many assets as a shop. Buyers find it easier to reach merchandise with online sales during a pandemic, but buyers must pay an online food delivery service fee that delivers products in the form of food or goods ordered. 


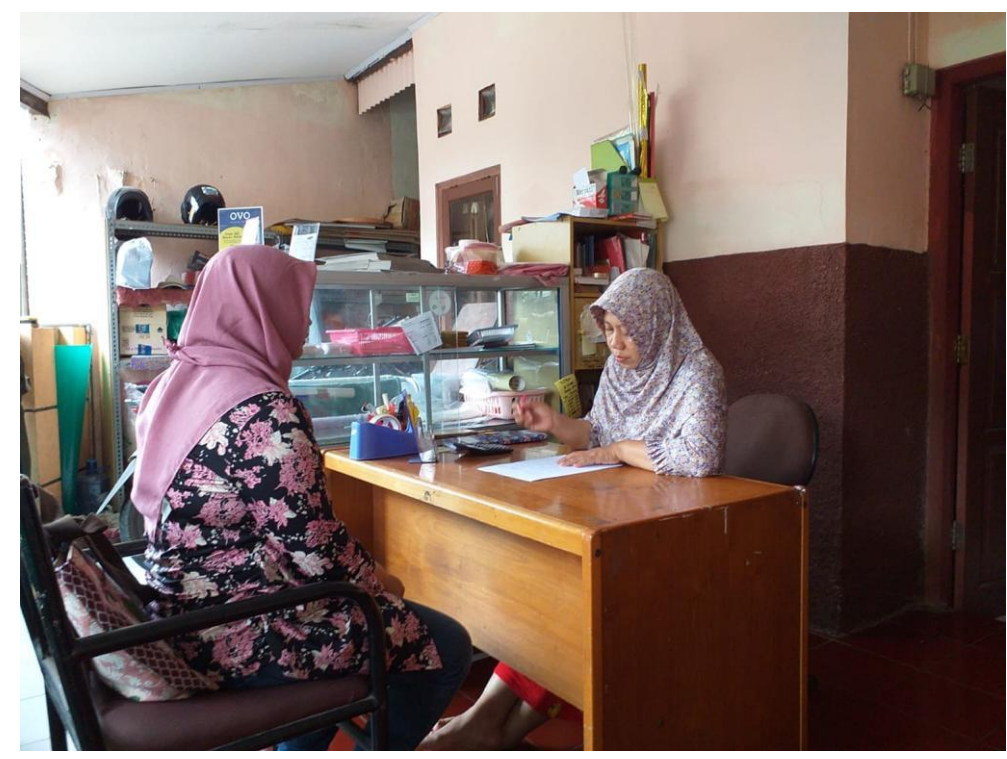

Fig. 2. Interview With Mrs. Isma Rahayu, Owner of Wingko Babat Cap Pohon Kelapa.

\subsection{Implement Health Protocols When Selling Offline}

The interview with Mrs Tri was conducted at Mrs Tri's house. Mrs Tri is one of the owners of a chicken rice stall in the chicken rice village. In this village, almost all residents of the village work as sellers of chicken rice. Mrs Tri is also helped by selling with her family.

Mrs Tri has to keep selling even though the pandemic continues. Mrs Tri strictly complies with government directives, such as not providing plastic straws, maintaining the cleanliness of sales stalls, and implementing health protocols. Mrs Tri applies a health protocol by using a mask, keeping her distance and providing a place to wash her hands. This was done by Mrs Tri so that she could continue selling (Interview with Mrs Tri).

SMEs owners should carry out government policies so that their business runs smoothly. Maintaining health protocols is also part of government policy. During a pandemic, SME owners or managers should implement and develop habits of maintaining health protocols. This is very useful for preventing the transmission of COVID-19. 


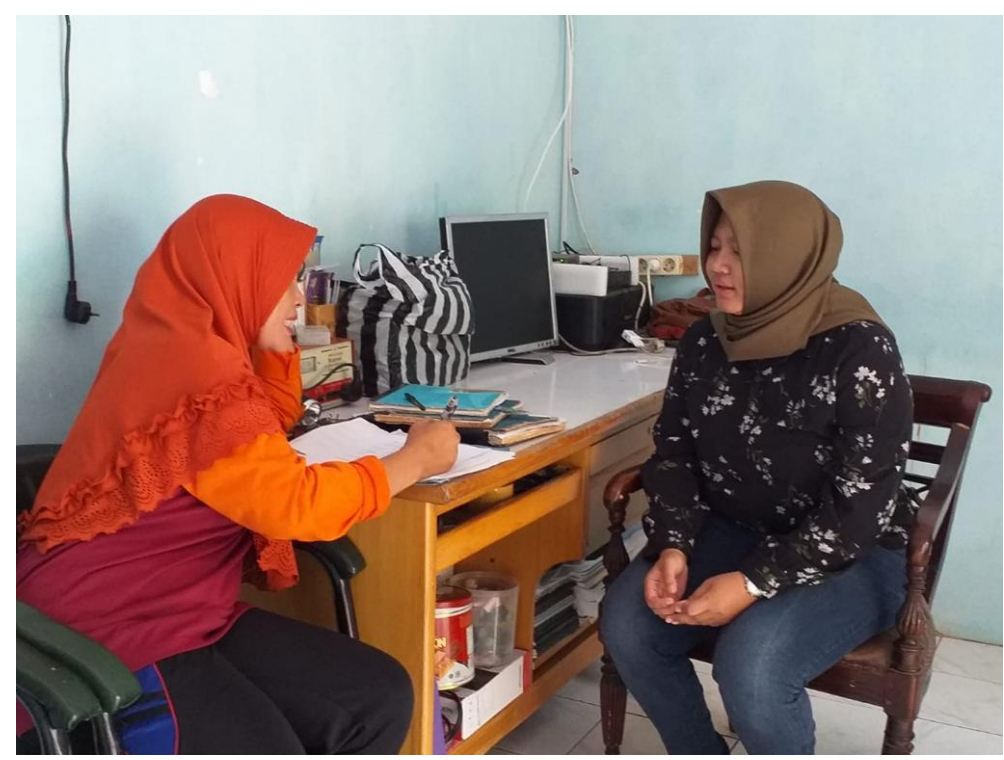

Fig. 3. Interview With Mrs. Tri Asih, Owner of Warung Nasi Ayam.

\subsection{Using Money or Goods Transfer Services}

The interview with Mrs Rini was conducted at Mrs Rini's house. Mrs. Rini is the owner of the Tlogo Kreasi Sulam Pita. She is a member of the ribbon embroidery group. His neighbours assisted her in running these SMEs as an employee. Every day his neighbour came to his house to help work on the product.

During a pandemic like this, Mrs Rini relies on money transfer services (transfers) to pay for products and uses courier services to deliver her products. In addition, Mrs Rini also added making masks for a side business during the pandemic. She did this to be able to maintain his SMEs in order to remain profitable. Mrs Rini also aims to maintain her SMEs during the pandemic still to pay her employees (Interview with Mrs Rini).

Buyers and sellers can not meet in-person to be able to transact. Sellers can market their products through social media (such as Instagram, Facebook or WhatsApp) or online shopping applications. When there is an agreement between the buyer and seller regarding the price of the goods and shipping costs, the buyer can make a payment using a money transfer. After the goods are paid for, the seller can deliver the goods via courier. After the buyer gets the goods, the buyer can confirm that the goods have arrived. 


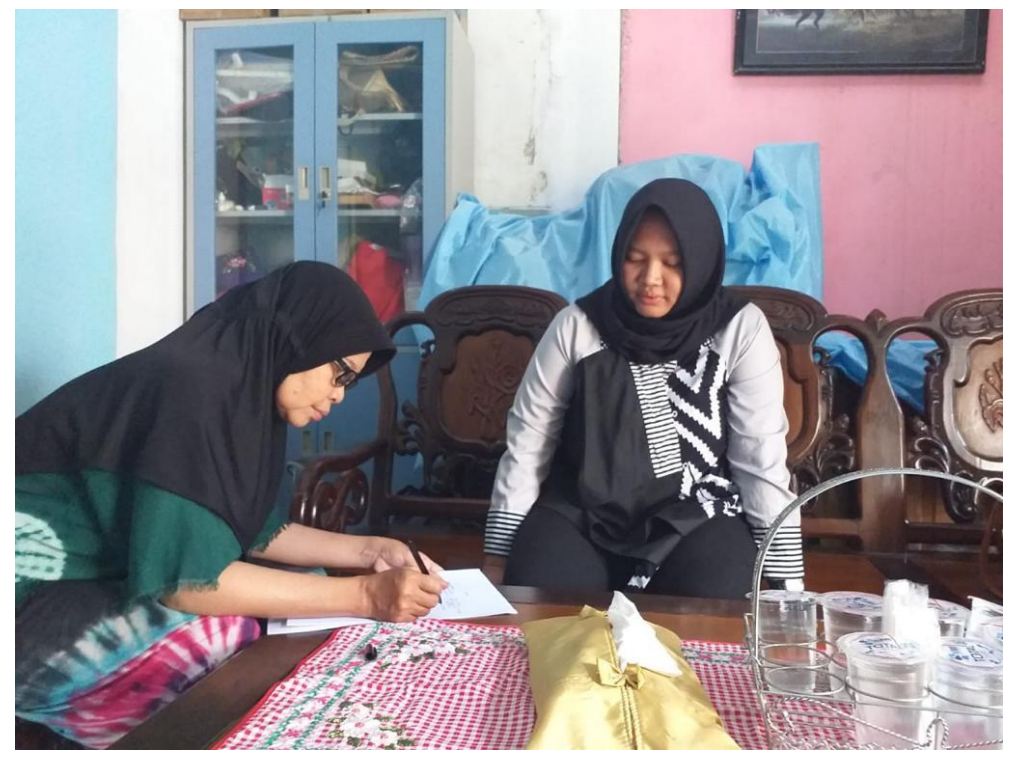

Fig. 4. Interview With Mrs. Rini, Owner of Tlogo Kreasi Sulam Pita.

\section{Conclusions}

The COVID-19 pandemic has affected several SMEs in Semarang City and even resulted in temporary closure. SMEs need a change in organizational culture in SMEs management in order to maintain their business. Changes in organizational culture in SME management include switching from selling offline to selling online, implementing health protocols when running offlined and using money and goods transfer services to avoid meeting directly with consumers during a pandemic. By making changes to the organizational culture in the management of SMEs, SMEs can continue to benefit and avoid bankruptcy.

\section{Reference}

1. I. C. Sanjaya. Antara Jateng. 1.538 UMKM di Semarang terdampak pandemi COVID-19, (2020)

2. C. Icensee, F. Teuteberg, K. M. Griese, C. Topi, The Relationship between organizational culture, sustainability, and digitalization in SMEs: A systematic review, Journal of Cleaner Production, 275 (2020)

3. A. N. Sow, R. Basiruddin, J. Mochammad, S. Zaleha, A. Rasyid, Fraud prevention in malaysia small and medium enterprises (SMEs), Journal of Financial Crime, (2017)

4. F. Fitriasari, How do small and medium enterprise (SME) survive the covid-19 outbreak, Jurnal Inovasi Ekonomi, (2020)

5. V. Supyuenyong, N. Islam, U. Kulkarni, Influence of SME characteristics on knowledge management processes, Journal of Enterprise Information Management, (2009).

6. J. Freiling, SME management - What can we learn from entrepreneurship theory, SSRN Electronic Journal, (2007)

7. J. Fourth, A. Bryson, Management practices and SME performance, Scottish Journal of Political Economy, (2019) 
8. A. Ates, P. Garengo, P. Cocca, U. Bititci, The Development of SME managerial practice for effective performance management, Journal of Small Business and Enterprise Development, (2013)

9. J. Arthur, M. Wang, R. Coe, L. V. Hedges, Research methods and methodologies in education, (2012)

10. L. A. Goodman, Snowball Sampling, JSTOR Journal, (1961) 